\title{
PCV and plasma biochemistry in relation to fitness of horses competing in endurance rides
}

\author{
P. Jahn', Helena Härtlová2, M. Mal’3, R. Kabe ${ }^{1}$ and J. Hanák \\ ${ }^{1}$ University of Veterinary and Pharmaceutical Sciences, Clinic of equine medicine, Brno, Czech Republic \\ ${ }^{2}$ City Hospital, Cesk" Brod, Czech Republic \\ ${ }^{3}$ City Hospital, Moravská Trebová, Czech Republic
}

\begin{abstract}
Summary
Thirty-seven horses competing in endurance rides over the distances of 45-80 km were investigated. Assessment of fitness was performed in all horses according to the official FEl Rules for endurance rides (1986) before, during and in the end of rides. Only horses having passed successfully through the veterinary inspections were qualified (their average speed was $14.9 \pm 2.7 \mathrm{~km} / \mathrm{h}$ ). PCV and selected biochemical values were determined in all horses.

Increase in PCV, TPP, lactate, CK, AST (all $\mathrm{P}<0.01)$ values, $\mathrm{pH}(\mathrm{p}<0.05)$ and decrease in $\mathrm{K}(\mathrm{p}<0.05)$ and $\mathrm{Cl}(\mathrm{p}<0.01)$ concentrations were observed in the group of 28 qualified horses. Increase in PCV, TPP $(p<0.01)$, lactate and CK $(p<0.05)$ values and decrease in CI concentration $(p<0.05)$ were observed in unqualified horses. Differences between the two groups occurred in post exercise values of $P C V(p<0.01)$ and TPP $(p<0.05)$.
\end{abstract}

Keywords: $\quad$ horse, endurance ride, PCV, plasma biochemistry, fitness

\begin{abstract}
Hämatokrit und biochemische Plasmavariablen im Vergleich zur Fitness von Pferden während eines Distanzrittes
Im Verlauf von Distanzritten mit einer Länge von 45 - 80 km wurden 37 Pferde untersucht. Der Fitness-Zustand der Pferde wurde gemäß der offiziellen FEl Richtlinien für Distanzritte (1986) vor Beginn, während und nach Beendigung des Rittes kontrolliert (klinische Untersuchung, Messen der Herz- und Atemfrequenz). Es qualifizierten sich nur solche Pferde, die alle Tierarztkontrollen erfolgreich bestanden hatten. Die durchschnittliche Rittgeschwindigkeit dieser Pferde betrug 14,9 $\pm 2,7 \mathrm{~km} / \mathrm{h}$. Blutproben wurden zu folgenden Zeitpunkten genommen: 90-60 min vor dem Ritt, bei den qualifizierten Pferden 30 min nach Beendigung des Rittes, bei den nicht qualifizierten Pferden unmittelbar nach inrem Ausschluß durch den Tierarzt (d.h. nach einer Pause von ca. 30 min). Bei allen Pferden wurden Hämatokrit (packed cell volume, PCV) und ausgewählte biochemische Variablen bestimmt.

In der Gruppe der qualifizierten Pferde (28 Pferde) wurde ein Anstieg im Hämatokrit, der Gehalte an Gesamteiweiß (total plasma protein, TPP), Laktat, CK und AST (jeweils $p<0,01)$ und des pH-Wertes $(p<0,05)$, sowie ein Abfall der Konzentrationen an Kalium $(p<0,05)$ und Chlorid $(p<0,01)$ beobachtet. Bei den nicht qualifizierten Pferden stiegen die Werte von PCV, TPP $(p<0,01)$, Laktat und CK $(p<0,05)$, die Chloridkonzentration nahm ab $(p<0,05)$. Zwischen den beiden Gruppe bestanden nach Belastung Unterschiede in den Werten von PCV $(p<0,01)$ und TPP $(p<0,05)$.
\end{abstract}

Schlüsselwörter: Pferd, Distanzritt, Hämatokrit, biochemische Plasmavariablen, Fitness

\section{Introduction}

Many studies concerning the metabolic response of horses to prolonged exercise have been carried out in the last 30 years. Some of them have been done to find out relationships between clinical assessment of horse's fitness and its plasma biochemistry and/or haematology changes during exercise (Rose, 1983; Grosskopf and Van Rensburg, 1983; Kerr and Snow, 1983).

The accuracy of a clinical assessment of the horse according to the current Fédération Equestre International (FEI) Rules for Endurance Riding (1986) in determining the fitness of horses competing over the distances of 87 to $100 \mathrm{~km}$ has been judged in the study of Sloet van Oldruitenborgh-Oosterbaan et al. (1991).

The aims of our study were:

1. to determine relationships between clinical assessment of fitness according to the FEI Rules for Endurance Riding (1986) in horses competing over distances of $45-80 \mathrm{~km}$ and their PCV (packed cell volume) and selected biochemical parameters,

2. to determine relationships between speed of horses and their PCV and selected blood biochemistry values.

\section{Materials and methods}

Endurance ride protocol

Thirty-seven horses, (6 thoroughbreds, 21 warm blood, 7 Arabian, 2 cross bred horses and 1 Welsh pony) competing in endurance rides over the distances of $45 \mathrm{~km}$ (8 horses), $50 \mathrm{~km}$ (24 horses), $60 \mathrm{~km}$ (2 horses) and $80 \mathrm{~km}$ (3 horses), were permitted to enter the study by their owners. The distances covered in each year and the numbers of horses competing in the ride, horses investigated and horses unqualified are listed in table 1.

All horses, regularly trained for endurance rides, but of varying degree of fitness, carried weights of 75 to $95 \mathrm{~kg}$ (including equipment). The weather during the competition was dry and warm (temperature about $25^{\circ} \mathrm{C}$ ).

The assessment of fitness according to FEl Rules for Endurance Riding (1986) (clinical examination, heart and respiratory rate measurements) was performed before the start, before the compulsory 30 minutes rest period after $25 \mathrm{~km}$ (in 45, 50 and $80 \mathrm{~km}$ rides), $30 \mathrm{~km}$ (in $60 \mathrm{~km}$ ride), and $50 \mathrm{~km}$ (in $80 \mathrm{~km}$ ride), and until 30 minutes after finishing the ride. Only horses with heart rate 
Tab. 1: Distances of endurance rides and numbers of horses covered in the experiment

\begin{tabular}{|c|c|c|c|c|c|c|c|c|}
\hline \multirow[t]{2}{*}{$\begin{array}{l}\text { Year } \\
\text { competing }\end{array}$} & \multirow[t]{2}{*}{$\begin{array}{c}\text { Distance } \\
(\mathrm{km})\end{array}$} & \multirow[t]{2}{*}{$\begin{array}{c}\text { Total number } \\
\text { of horses }\end{array}$} & \multicolumn{2}{|c|}{$\begin{array}{l}\text { Total number } \\
\text { of disqualified } \\
\text { horses }\end{array}$} & \multirow[t]{2}{*}{$\begin{array}{c}\text { Total number } \\
\text { of sampled } \\
\text { horses }\end{array}$} & \multicolumn{2}{|c|}{$\begin{array}{c}\text { Number of } \\
\text { disqualified sampled } \\
\text { horses }\end{array}$} & \multirow[t]{2}{*}{$\begin{array}{c}\text { Winner's } \\
\text { speed }(\mathrm{km} / \mathrm{h})\end{array}$} \\
\hline & & & $\begin{array}{l}\text { eliminated in } \\
\text { half the ride }\end{array}$ & $\begin{array}{l}\text { disqualified } \\
\text { in the end }\end{array}$ & & $\begin{array}{l}\text { eliminated in } \\
\text { half the ride }\end{array}$ & $\begin{array}{l}\text { disqualified } \\
\text { in the end }\end{array}$ & \\
\hline \multirow[t]{2}{*}{1990} & 45 & 11 & 3 & 0 & 8 & 2 & 0 & 20.93 \\
\hline & 60 & 3 & 1 & 0 & 2 & 1 & 0 & 17.30 \\
\hline \multirow[t]{2}{*}{1991} & 50 & 8 & 1 & 1 & 5 & 1 & 1 & 13.62 \\
\hline & 80 & 3 & 0 & 0 & 3 & 0 & 0 & 16.01 \\
\hline 1992 & 50 & 12 & 0 & 3 & 9 & 0 & 2 & 19.30 \\
\hline 1993 & 50 & 12 & 1 & 1 & 3 & 0 & 1 & 14.71 \\
\hline 1994 & 50 & 13 & 0 & 1 & 7 & 0 & 1 & 14.15 \\
\hline
\end{tabular}

$(\mathrm{HR})$ and respiratory rate (RR) below permitted limits (HR: 64 BPM, RR: 48 RPM) were allowed to continue in the ride and qualified in the end (group qualified). Horses with excessive HR and/or RR were eliminated before rest period (group eliminated) or disqualified in the end (group disqualified). Before every veterinary inspection, riders could wait a maximum of 30 minutes for $H R$ and RR to drop to limit values.

The net time for each individual horse was measured during the ride.

\section{Blood sampling and analyses}

Jugular blood samples were collected 90-60 minutes before the ride and 30 minutes after the qualified horses finished the ride. In unqualified (i.e. eliminated and disqualified) horses, the blood was taken immediately after their veterinary inspection (i.e. after approximately 30 minutes of rest).

Values of packed cell volume (PCV), total plasma protein (TPP), lactate, glucose, creatine phosphokinase (CK), aspartate aminotransferase (AST), $\mathrm{Na}, \mathrm{K}, \mathrm{Cl}, \mathrm{pH}, \mathrm{pCO}_{2}$, plasma bicarbonate $\left(\mathrm{HCO}_{3}\right)$ and base excess (BE) were determined.

Samples for packed cell volume (PCV) analysis were collected in glass tubes containing EDTA. PCV values were determined by microhaematocrit centrifugation.

Samples for TPP, lactate, glucose, CK, AST, Na, $\mathrm{K}$ and $\mathrm{Cl}$ values determination were collected in plastic tubes with addition of $\mathrm{li}$ thium heparin (5 i. u./ml of blood). Plasma was separated immediately after collection and frozen using dry ice. Spectrophotometric was used to determine TPP (biureth reaction), lactate (Sigma Chemical, UK), glucose (Lachema, Czechoslovakia), CK (Biogema Ko $\pi$ ice, Czechoslovakia), AST (Boehringer Mannheim, Germany) and $\mathrm{Cl}$ (Lachema, Czechoslovakia). Plasma sodium and potassium values were determined using flame photometry.

Blood gas and acid-base changes during the endurance ride were evaluated in 20 horses. Samples for blood gas determination were collected in heparinised glass syringes and immediately cooled in ice bath until analysis. Blood gas and acid-base analysis was performed using Radiometer ABL 300 (Denmark) on the day of collection.

\section{Data analysis}

The race speed was calculated from the time measured for each individual horse. Means and SD of speed, PCV and biochemical values were calculated.
Differences between pre and post exercise values were determined using the t-test for paired data. Statistical differences in pre and post exercise values between qualified and unqualified horses (group eliminated and disqualified) were calculated using the Student's t-test. The same test was used for statistical analysis of differences between the horses eliminated and those disqualified in the end.

Relationships between speed of each horse and its PCV and biochemical values were evaluated using the correlation analysis.

\section{Results}

Nine horses (2 participants of $45 \mathrm{~km}$ ride, 6 participants of $50 \mathrm{~km}$ ride and 1 participant of $60 \mathrm{~km}$ ride) were not qualified (unqualified) because their heart rates were above the limit value. Four of them were eliminated after veterinary inspection at the first rest period, five of them were disqualified during the final veterinary inspection. Clinical signs of myoglobinuria developed in one of the horses eliminated at the first rest period of $60 \mathrm{~km}$ ride approximately two hours after its elimination.

Average speed of qualified horses was $14.9 \pm 2.7 \mathrm{~km} / \mathrm{h}$.

Pre and post ride plasma PCV and biochemical values are shown in Table 2, significance of differences in Table 3. Increases in PCV, TPP, lactate, CK, AST (all $\mathrm{P}<0.01)$ values, $\mathrm{pH}(\mathrm{p}<0.05)$ and decreases in $\mathrm{Cl}(p<0.01)$ and $\mathrm{K}(\mathrm{p}<0.05)$ concentrations were observed in the 28 horses that qualified during the endurance ride. Increases in PCV, TPP $(p<0.01)$, lactate and CK $(p<0.05)$ values and decreases in $\mathrm{Cl}$ concentration $(\mathrm{p}<0.01)$ were observed in eliminated and disqualified horses.

No significant differences between the group of 27 qualified and 9 unqualified (eliminated and disqualified) horses were found in pre exercise PCV and/or biochemical values (table 3). Significant differences occurred in post exercise values of PCV $(0.45 \pm 0.08 \mathrm{l} / \mathrm{l}$ qualified, $0.54 \pm 0.06 \mathrm{I} / \mathrm{l}$ unqualified, $\mathrm{p}<0.01)$ and TPP $(74.9 \pm 9.2 \mathrm{~g} / \mathrm{l}$ qualified, $84.2 \pm 12.1 \mathrm{~g} / \mathrm{l}$ unqualified, $\mathrm{p}<0.05$ ).

The only significant difference between horses eliminated before the rest period and disqualified in the end occurred in TPP. Pre exercise TPP value was $61,8 \pm 3,4 \mathrm{~g} / \mathrm{l}$ in four eliminated horses and $69,0 \pm 4,7 \mathrm{~g} / \mathrm{l}$ in five disqualified horses $(\mathrm{p}<0.05)$. Post exercise values were $75,0 \pm 9,0 \mathrm{~g} / \mathrm{l}$ and $91,6 \pm 9,0 \mathrm{~g} / \mathrm{l}$, respectively $(p<0.05)$. 
Tab. 2: Changes of hematological and biochemical values in horses during the endurance rides

\begin{tabular}{|l|l|l|l|l|}
\hline & \multicolumn{2}{|c|}{ Qualified horses } & \multicolumn{2}{c|}{ Disqualified horses } \\
\hline Parameter & Pre ride & Post ride & Pre ride & Post ride \\
\hline PCV $(\mathrm{l} / \mathrm{l})$ & $0.391 \pm 0.073$ & $0.446 \pm 0.083$ & $0.414 \pm 0.047$ & $0.540 \pm 0.058$ \\
\hline $\mathrm{TPP}(\mathrm{g} / \mathrm{l})$ & $67.8 \pm 6.4$ & $74.9 \pm 9.2$ & $65.8 \pm 5.5$ & $84.2 \pm 12.1$ \\
\hline Lactate $(\mathrm{mmol} / \mathrm{l})$ & $1.25 \pm 0.38$ & $2.45 \pm 1.49$ & $1.2 \pm 0.5$ & $2.3 \pm 0.9$ \\
\hline Glucose $(\mathrm{mmol} / /)$ & $6.0 \pm 0.7$ & $5.5 \pm 0.8$ & $6.7 \pm 1.6$ & $7.4 \pm 2.0$ \\
\hline $\mathrm{CK}(\mu \mathrm{kat} / \mathrm{l})$ & $5.0 \pm 3.1$ & $14.3 \pm 9.2$ & $5.1 \pm 3.0$ & $28.7 \pm 29.1$ \\
\hline $\mathrm{AST}(\mu \mathrm{kat} / \mathrm{l})$ & $5.5 \pm 1.7$ & $7.1 \pm 2.4$ & $5.9 \pm 3.9$ & $7.5 \pm 4.4$ \\
\hline $\mathrm{Na}(\mathrm{mmol} / \mathrm{l})$ & $133.6 \pm 7.0$ & $135.8 \pm 9.3$ & $134.4 \pm 7.7$ & $135.9 \pm 9.9$ \\
\hline $\mathrm{K}(\mathrm{mmol} / \mathrm{l})$ & $3.9 \pm 0.7$ & $3.5 \pm 0.4$ & $4.4 \pm 0.6$ & $3.7 \pm 0.3$ \\
\hline $\mathrm{Cl}(\mathrm{mmol} / \mathrm{l})$ & $103.5 \pm 6.7$ & $96.1 \pm 5.4$ & $100.2 \pm 5.3$ & $93.9 \pm 3.4$ \\
\hline $\mathrm{pH}$ & $7.386 \pm 0.027$ & $7.414 \pm 0.036$ & $7.400 \pm 0.020$ & $7.408 \pm 0.025$ \\
\hline $\mathrm{pCO}(\mathrm{kPa})$ & $6.3 \pm 0.7$ & $6.2 \pm 0.7$ & $6.2 \pm 0.9$ & $5.8 \pm 1.0$ \\
\hline $\mathrm{SBC}(\mathrm{mmol} / \mathrm{l})$ & $25.8 \pm 1.9$ & $26.3 \pm 3.0$ & $26.3 \pm 1.1$ & $25.3 \pm 2.2$ \\
\hline $\mathrm{BE}(\mathrm{mmol} / \mathrm{l})$ & $2.6 \pm 2.4$ & $4.2 \pm 3.5$ & $2.9 \pm 1.4$ & $1.9 \pm 2.8$ \\
\hline
\end{tabular}

The only statistically significant correlation was found between the speed of qualified horses and their BE value $\left(r_{2}=-0.75, p<0.01\right)$, expressed by equation:

$$
\mathrm{BE}(\mathrm{mmol} / \mathrm{l})=20.4-1.1 \times \mathrm{v}(\mathrm{km} / \mathrm{h}) .
$$

\section{Discussion}

PCV and TPP are considered indicators of hemoconcentration during exercise (Carlson, 1987). Pre-ride values of both of these parameters similar to those of our study were found in previous works by Carlson and Mansmann (1974), Rose et al. (1977), Lucke and Hall (1980), Grosskopf et al. (1983) and Sloet van Oldruitenborgh-Oosterbaan (1991).

Only in the last of above mentioned studies differences of preexercise PCV and TPP values between qualified and disqualified horses were statistically evaluated and, in contrast with our results, the significant difference of pre-exercise TPP between two groups of horses was found.

Rose et al. (1977) showed significant differences between qualified and disqualified (or fit and less fit) horses in post ride PCV and/or TPP values after $100 \mathrm{~km}$ ride. Sloet van Oldruitenborgh-Oosterbaan (1991) reported similar findings after $87-100 \mathrm{~km}$ rides. The results of our study were similar despite the different distances of endurance rides. This suggests that qualified horses from these studies were able to adjust their water balance during exercise regardless of the duration, while the less fit horses were not able to balance water loss even during exercise of shorter distances.

The plasma lactate concentration increased significantly and similarly in both groups of horses. A relatively small rise in lactate concentration demonstrates that horses worked in their aerobic capacity as described earlier (Grosskopf and Van Rensburg, 1983; Lucke and Hall, 1980). Unlike results of Sloet van Oldruitenborgh-Oosterbaan (1991), significant differences in lactate concentration between qualified and unqualified horses were not found.
Tab. 3: Statistical significance of differences in PCV and plasma biochemical values between groups of qualified and unqualified horses

\begin{tabular}{|l|c|c|c|c|}
\hline Parameter & 1. & 2. & 3. & 4. \\
\hline PCV & $p<0,01$ & $p<0,01$ & & \\
\hline TPP & $p<0,01$ & $p<0,01$ & $p<0,05$ & $p<0,05$ \\
\hline Lactate & $p<0,01$ & $p<0,05$ & & \\
\hline Glucose & & & & \\
\hline $\mathrm{CK}$ & $p<0,01$ & $p<0,05$ & & \\
\hline AST & $p<0,01$ & & & \\
\hline $\mathrm{Na}$ & & & & \\
\hline $\mathrm{K}$ & $\mathrm{p}<0,05$ & & & \\
\hline $\mathrm{Cl}$ & $\mathrm{p}<0,01$ & $\mathrm{p}<0,01$ & & \\
\hline $\mathrm{pH}$ & $\mathrm{p}<0,05$ & & & \\
\hline $\mathrm{pCO}$ & & & & \\
\hline $\mathrm{SBC}$ & & & & \\
\hline $\mathrm{BE}$ & & & & \\
\hline
\end{tabular}

1. pre-ride qualified vs. post-ride values unqualified

2. pre-ride non qualified vs. post-ride values in unqualified

3. pre-ride values in qualified vs. unqualified

4. post-ride values in qualified vs. unqualified

In contrast with the plasma glucose drop observed by Lucke and Hall $(1987,1980)$ and Sloet van Oldruitenborgh-Oosterbann (1991), there was no difference in plasma glucose concentration between qualified and unqualified horses. However, distances in our experiment were much shorter in comparison with above cited studies.

A large significant increase in CK and a small rise in AST activities were observed during the ride.

Although the difference in post-ride CK activity between the group of qualified and unqualified horses was great, statistical significance was not found, probably because of large individual variations. The observed CK increase is consistent with earlier findings of Kerr and Snow (1983) and Rose (1983). However, Rose et al. (1977), in contrast to Kerr and Snow (1983), found a significant difference in post exercise CK activities between the qualified and disqualified horses competing over the distance of $100 \mathrm{~km}$.

A smaller rise in AST activity in both groups corresponds to previous findings of Kerr and Snow (1983) and Cardinet et al. (1967), who reported that the effect of exercise on plasma AST activity is inconsistent. The average increase in AST activity in our study was very similar in both groups of horses. On the contrary, Sloet van Oldruitenborgh-Oosterbann (1991) described a much higher increase in AST activity in disqualified horses after $100 \mathrm{~km}$ endurance ride.

In our study, one of the $60 \mathrm{~km}$-ride participants in 1990 was eliminated during veterinary inspection on the 30th kilometre because its HR was above limit value. Signs of myoglobinuria developed within one hour in this horse. The same horse won the $80 \mathrm{~km}$ ride the following year. Interestingly CK activities in samples taken 30 minutes after that horse's elimination (1990) and 30 minutes after 
finishing the ride (1991) were similar (40.4 ukat/l and 40.9 ukat//, respectively).

From results of most above mentioned authors and our study we can conclude that elevated CK and AST activities in endurance horses may be a common occurrence, and they should not be interpreted as an indicator of muscle damage unless clinical evidence of disease is also present.

Changes of plasma sodium described in the literature are variable. Some authors found the plasma sodium concentrations to rise (Rose et al., 1977; Lucke and Hall, 1980), others found it to decrease (Carlson and Mansmann, 1974), while another (Lucke and Hall, 1978) found no difference between the pre-ride and post-ride values. Observed differences could be due to different climatological circumstances. However, the sodium concentration does not provide a reliable guide to net sodium balance because it reflects the exchangeable cation content (Carlson, 1987).

The decreased plasma potassium concentration, described previously by many authors (Carlson and Mansmann, 1974; Rose et al., 1977; Lucke and Hall, 1978, 1980) probably reflects the loss by sweating and only partial replenishment at the expense of intracellular potassium.

The greater loss of chloride relative to the other electrolytes in our study can be explained by high concentration of chlorides in sweat in comparison with sodium (Carlson, 1975).

The fact, that there were no significant differences in serum electrolyte concentrations between the qualified and unqualified horses suggests that neither qualified nor eliminated and disqualified horses had serious problems in their electrolyte balance.

In contrast to the results of Milne (1974) who did not find any changes in $\mathrm{pH}$ during a $80 \mathrm{~km}$ endurance ride, we measured a rise of $\mathrm{pH}$ in the horses of our study. It is similar to acid base status changes described in human long distance runners (Mácek and Vávra, 1988). The significant increase of $\mathrm{pH}$ in qualified horses is probably caused by increased $\mathrm{pCO}_{2}$ elimination due to hyperventilation. BE increase can be connected with the excessive chloride loss during the endurance ride.

Interestingly, pre- and post-ride TPP values were higher in the group of horses disqualified in the end of the ride than in the horses eliminated. We can not exactly interpret these differences because of the small amount of horses in both groups.

The presented results suggest that HR and RR measurement according to the official FEl Rules for endurance rides (1986) are of the best indicators of the fitness of horses that mainly depends on hydration status of the organism. A good indicator of exercise intensity in the endurance ride appears to be the BE value.

\section{References}

Cardinet, G. H., Littrell, J. F. and Freedland, R. A. (1967): Comparative investigations of serum creatine phosphokinase and glutamic-oxaloacetic transaminase activities in equine paralytic myoglobinuria. Res. Vet. Sci. 8, 219-226.

Carlson, G. P. (1975): Fluid and electrolyte alterations in endurancetrained horses. Proceedings First International Symposium on Equine Hematology, 473-480.

Carlson, G. P. (1987): Hematology and body fluids in the equine athlete: a review. In: Equine exercise physiology 2. Gillespie, J. R., Robinson, N. E. (Eds.) ICEEP Publications Davis, 1st ed.
Carlson, G. P. and Mansmann, R. A. (1974): Serum electrolyte and plasma protein alterations in horses used in endurance rides. JAVMA 165, 262-264.

Fédération Equestre Internationale (1986): Rules for endurance riding. $2^{\text {nd }}$ ed. (effective $1^{\text {st }}$ April 1986) F.E.C. Bern Switzerland.

Grosskopf, J. F. W. and Van Rensburg, J. J. (1983): Some observations on the haematology and blood biochemistry of horses competing in $80 \mathrm{~km}$ endurance rides. In: Equine exercise physiology. Snow, D. H., Persson, S. G. B., Rose, R. J. (Eds.) Granta Editions Cambridge, $1^{\text {st }}$ ed.

Grosskopf, J. F. W., Van Resburg, J. J. and Bertschinger, H. J. (1983): Haematology and blood biochemistry of horses during a $210 \mathrm{~km}$ endurance ride. In: Equine exercise physiology. Snow, D. H., Persson, S. G. B., Rose, R. J. (Eds.) Granta Editions Cambridge, $1^{\text {st }}$ ed.

Kerr, M. G. and Snow, D. H. (1983): Plasma enzyme activities in endurance horses. In: Equine exercise physiology. Snow, D. H., Persson, S. G. B., Rose, R. J. (Eds.) Granta Editions Cambridge, $1^{\text {st }}$ ed.

Lucke, J. N. and Hall, G. M. (1978): Biochemical changes in horses during a 50-mile endurance ride. Vet. Rec. 102, 356-358.

Lucke, J. N. and Hall, G. M. (1980): Long distance exercise in the horse: Golden Horseshoe Ride 1978. Vet. Rec. 106, 405-407.

Mácek, M. and Vávra, J. (1988): Fyziologie a patofyziologie télesné zátëže. Avicenum Prague, $2^{\text {nd }}$ ed.

Milne, D. W. (1974): Blood gases, acid-base balance and electrolyte and enzyme changes in exercising horses. J. S. Afr. veter. Assoc., 45, 345-354.

Rose, R. J. (1983): An evaluation of heart rate and respiratory rate recovery for assessment of fitness during endurance rides. In: Equine exercise physiology. Snow, D. H., Persson, S. G. B., Rose, R. J. (Eds.) Granta Editions Cambridge, $1^{\text {st }}$ ed.

Rose, R. J., Purdue, R. A. and Hensley, W. (1977): Plasma biochemistry alterations in horses during an endurance ride. Equine vet. J. 9, 122-126.

Sloet van Oldruitenborgh-Oosterbaan, M. M., Wensing, Th., Barneveld, A. and Breuknik, H. J. (1991): Heart rate, blood biochemistry and performance of horses competing in a $100 \mathrm{~km}$ endurance ride. Vet. Rec. 128, 175-179.

\section{Petr Jahn}

Radovan Kabe

Jaroslav Hanák

University of Veterinary and Pharmaceutical Sciences

Clinic of equine medicine,

Palackého 1-3

61242 Brno

Czech Republic

Helena Härtlová

City Hospital

česk" Brod

Czech Republic

Milan Mal"

City Hospital

Moravská Trebová

Czech Republic 